\title{
Internet resources in gay and lesbian studies
}

\author{
By Robert B. Marks Ridinger
}

\section{For information on homosexual issues get "Out on the Net"}

$\mathbf{T}$ he last several years have witnessed the swift coalescence of gay and lesbian studies as both an academic subject and a popular research focus in virtually every discipline of the humanities and social sciences and in biology. Along with the sharp increase in monographs and journal articles has come a virtual explosion of Internet sites relating in some fashion to the life, culture, and issues of the gay and lesbian communities, both within the United States and worldwide. Many of these sites presuppose a degree of familiarity with subcultural jargon and abbreviations by using in their names slang terms, such as "queer," which may not be the most obvious of choices to the general searcher.

The pattern of site creation is very different from many other subject fields, centering upon individual organizations ranging from blatantly political activist groups to professional caucuses (the latter having hegun with ALA's Gay and Lesbian Task Force in 1970). In an effort to cope with the sheer number of individual homepages carrying information relating to the gay and lesbian communities (and the speed with which new sites appear), this listing focuses on identifying those sites with the broadest potential audience and greatest value for reference work. General access points such as the Queer Resources 1)irectory should be checked regularly for expanded and updated coverage of specific topics or information on newly founded groups.

\section{Gateways}

Given the diversity of the gay and lesbian communities, beginning searchers may wish to orient themselves by visiting some of the sites that attempt to provide gateways to a large number of links. Standard search engines such as Yahoo, Lycos, and Altavista may be of limited value for locating gay and lesbian information.

- Queer Resource Directory. One of the longest established gay directory sites and the model for orhers, with 16,494 files on every aspect of lesbian and gay culture. Access: http: //www.qrd.org/qrd/.

- Gay and Lesbian Resources. A subdirectory of the Rainbow Cafe. Access: hitp:// www.3wnet.com/rainbow/gnl.html.

- Infoqueer. A general site offering homepages of individuals and organizations by geographic area of the world, e-mail lists and newsgroups, campus groups, publications, and transgender and transsexual resources. A featured link to PopcornQ, the primary site for queer films, is also provided. Access: http:// www.infoqueer.org/queer/qis/media.html.

- Out on the Net. A "virtual world" for lesbians and gays that blends creative content, individuals' rights, and community concerns. Access: http://www.comeout.com/

- Canada Gay, Lesbian and Bisexual Resources Directory. This offers links to all businesses and organizations that serve and support the homosexual and bisexual communities of Canada. Access: http://www.cglbrd.com/.

- Gaynet. One of the very first Internet sites to emerge as a focus for discussion on gay- and lesbian-related subjects, and still a highly active forum for debate. Access: majordomo@queernet.org; "subscribe gaynet." 
- PlanetOut: Gay and Lesbian News. The only major site devoted exclusively to monitoring news reports from the homosexual community worldwide. Limited archives available. Access: http://headlines.yahoo.com/planetout.

\section{Organizations}

- National Gay and Lesbian Task Force. Describing itself as "the frontline activist organization and national resource center for grassroots lesbian, gay, bisexual and transgender organizations," this site also includes press releases, full text of selected publications, and profiles of the "Creating Change" conferences. Access: http://www ngltf.org/.

- Human Rights Campaign. The United States' largest gay and lesbian lobbying organization, with emphases on comprehensive homosexual rights and AIDS. Access: www. hrcusa.org/

- Lambda Legal Defense and Education Fund. Founded in 1973, this is the largest legal organization working to secure civil rights for gays, lesbians, and persons with HIV via education, public policy work, and litigation. $A C$ cess: http://www.gaysource.com/gs/ht/oct95/ lambda.html.

- Gay and Lesbian Alliance Against Defamation. The only national gay and lesbian multimedia watchdog organization, dedicated to "promoting fair, accurate and inclusive representation as a means of challenging discrimination based on sexual orientation or identity." Site features include information on the creation of October as Lesbian and Gay History Month, the Freedom to Marry Project, and the GLAAD archives. Access: http:// www.glaad.org/.

- Digital Queers Home Page. A professional forum of gays and lesbians employed in the high technology industries, founded in 1992. Areas covered include lobbying for domestic partner benefits and challenging workplace stereotypes. Access: http://www.casti.com/dq/dq.html.

- National Directory of Gay and Lesbian Community Centers. Arranged by state and budget, this site is useful for locating local and regional service providers. A service of the Lesbian and Gay Community Center of New York. Access: http://www.gaycenter.org/natctr/.

- American Library Association Gay, Lesbian, and Bisexual Task Force. Founded in 1970 as the Task Force on Gay Liberation, this is the oldest professional homosexual caucus in the United States. Complete listings of all recipients of the Gay and Leshian Book Awards and conference programs are included. Access: www.outline.com/ala/ala.hp.html.

- PFLAG (Parents and Friends of Lesbians and Gays). A national nonprofit grassroots group dedicated to promoting the health and well-being of gay and lesbian people, their families, and friends through education and advocacy. Access: http://www.pflag.org/.

- Children of Lesbians and Gays Everywhere (COLAGE) publishes a quarterly newsletter and offers support groups for children age 12 and older. Access: KidsofGays@aol.com.

- Gay and Lesbian Parents Coalition International. With eighty chapters in eight countries, this organization offers support for lesbian mothers, gay fathers, bisexual parents, and the partners of their children. Topics regularly covered include custody, adoption, and surrogate parenting. Access: http://abacus.oxy.edu/ QRD/www/orgs/alpci/home.htm.

- International Association of Lesbian and Gay Pride Coordinators, Inc. An association of more than sixty cities worldwide that produce Gay and Lesbian Pride events yearly. Access: http://www/tde.com/ ialgpc/.

\section{Business}

- Lavender Pages. 'The online business directory for the San Francisco Bay Area gay, lesbian, and bisexual communities. Access: http://www.lavenderpages.com/.

\section{Libraries and archives}

- Queer Archives and Libraries Around the World. The best starting point for researchers unfamiliar with individual collections of this nature. Access: http://www.outline.com/saa/ archives.hp.html.

- James C. Hormel Gay and Lesbian Center and Collections (San Francisco Public Library). A showpiece of the new San Francisco Public Library, this major research center's collections focus on both the national and worldwide gay and lesbian communities. Information on the extensive archival holdings of the center, including the personal papers of late politician Harvey Milk and journalist Randy Shilts, is provided. Access: http://nick.sfpl.lils.ca. us/glcenter/homearly.htm.

- June L. Mazer Lesbian Collection (Los Angeles). Originally known as the West Coast Lesbian Collection, this is the only archive in the western United States "dedicated exclusively to preserving lesbian history." Holdings reach 


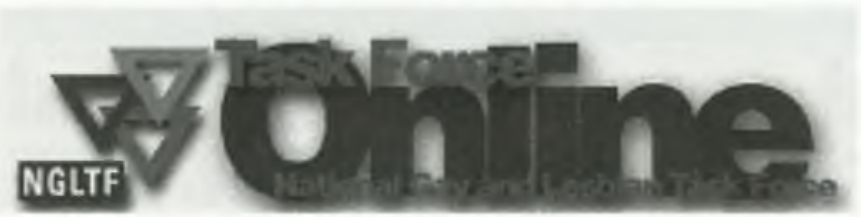

- Lesbian Herstory Archives (New York City). By far the premier site for beginning any research on the lesbian community of the United States. The Herstory col-

back to 1895 and include the papers of veteran lesbian activists Phyllis Lyon and Del Martin. Access: http://www.lesbian.org/mazer/ index.html.

- ONE Institute International Gay and Lesbian Archives (Los Angeles). Housed at the University of Southern California, this collection was formed in 1994 through the merger of the library of ONE (the oldest continuing homosexual activist group in the western hemisphere, founded in 1952) and the huge private collection of veteran activist Jim Kepner. $A C$ cess: http://www.usc.edu/Library/oneigla/.

- Gerber/Hart Library and Archives (Chicago). Founded in 1981, this collection's primary focus is on collecting and preserving the Midwest's homosexual and bisexual history. Access: http://www.gerberhart/org/.

- Canadian Gay and Lesbian Archives (Toronto). Created in 1973 by the collective that produced the newspaper the Body Politic, the archives' mission is "to collect and mainrain information and materials relating to the gay and lesbian movement in Canada and elsewhere." Access: http://www.web.net/archives/. Researchers investigating any aspect of Canadian way culture should also visit the site for the Archives Gaie du Quebec for the Francophone viewpoint on specific issues.

- Archives Gaie du Quebec. Collects and preserves all types of documentation (both paper and media) relating to the gay or lesbian communities of Quebec. Access: http:// www.er.uqam.ca/nobel/c2220/agq.html.

- Homodok (Amsterdam). One of the primary European archival collections on homosexual history, with holdings reaching back to 1870 and ranging from traditional sexology research to contemporary periodicals. Access: http://www.adamnet.nl/hldinfo.html.

- Gay, Lesbian, Bisexual and Transgendered Library/Archives of Philadelphia. One of the larger eastern libraries created by an urban community, founded in 1975. Special collections include the papers of activists Barbara Gittings, Kay Lahusen, and William Damon. Access: http://wanda.pond.com/ -stevecap/ la000001.htm. lection was begun in 1974 as the private library of lesbian feminists Joan Nestle and Deborah Edel. Holdings range from standard books and publications through unpublished diaries and clippings files to oral histories and videotapes. Access./www.intac.com/ kgs/lhef/index.html.

\section{Gay and lesbian studies}

- Programs in Gender and Lesbian, Gay and Bisexual Studies at Universities in the USA and Canada. Extensive coverage of established and developing degree and nondegree programs and research resources. Access: http: //www.duke.edu/web/jyounger/lbgprogs. html.

- QSTUDY-L (Queer Studies List). A forum for academic discussion of queer theory, an umbrella term covering homosexuality, bisexuality, and transgender. Access: qstudy1@acsu.buffalo.edu. Subscribe: listserv@acsu. buffalo.edu

\section{Minority gays and lesbians}

- GLBPOC (Gay, Lesbian and Bisexual People of Color). A general discussion list focusing on the issues of race and sexual orientation. Access: majordomo@abacus.oxy.edu. Subscribe: glbpoc.

- Blackstripe. Inspired by discussions on the Gay, Lesbian and Bisexual People of Color Board. Coverage offers a book list, current articles, films, and organizations. Access: http:// www.qrd.org/qrd/www/culture/black/.

- The Blacklist. A nationwide list of black lesbian and gay organizations. Access: http:// www.blk.com/blk/addrfrm.htm.

- National Deaf Queer Resource Center. Developed and maintained by the former head of San Francisco's Deaf Gay and Lesbian Center. Access: http://www.deafqueer.org/.

\section{Film}

- Popcornq. Based on the book The Ultimate Guide to Gay and Lesbian Video (Serpent's Tail, 1996), this site offers a massive filmography based on titles screened at the San Francisco Gay and Lesbian Film Festival plus a se-

(Internet cont. on page 671) 


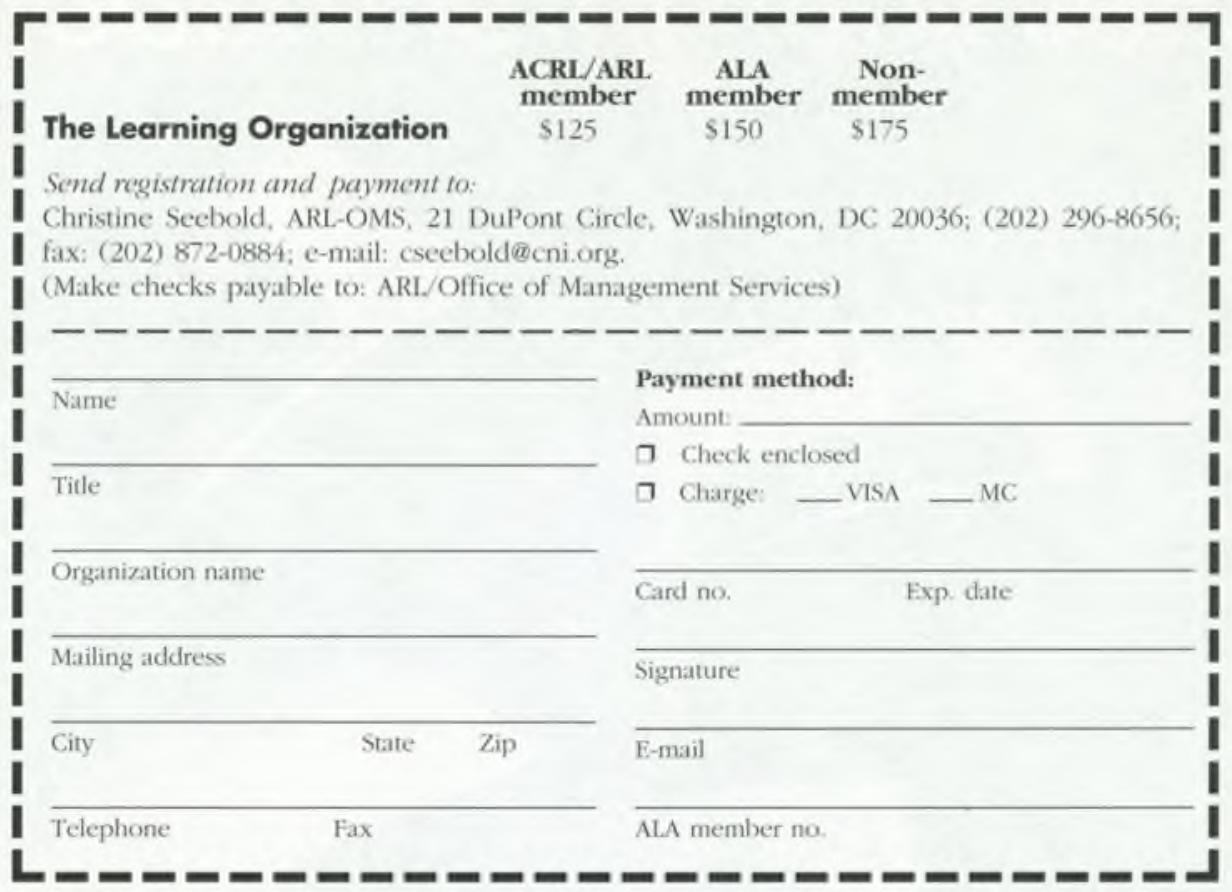

(Intemet cont. from page 660)

lection of feature films with gay, lesbian, transgender, or bisexual themes. Access: www.planetout.com/kiosk/popcornq

\section{Journalism}

- Queer Press International. A comprehensive site providing access to all aspects of gay and leshian journalism from weekly summaries and organizational news to Rex Wockner's international monitoring of gay and lesbian events worldwide. A particularly useful feature is the list of those publications that have Web addresses. Access: http://cyberzine.org/ html/GLAIDS/QPI/ qPipage.html.

- The ADVOCATE. Referred to as "the New York Times of gay America," this comprehensive magazine has been published since september 1967. Access: http://www.advocate.com.

- Harvard Gay and Lesbian Review. One of the leading new journals in the field of gay and lesbian studies. Access: http:// www.hglc.org/hglc/review.htm.

- Seattle Gay News Online. One of the major news sources for the Pacific Northwest's gay community. Access: http://www.sgn.org/sgn.

- Out in the Mountains. Vermont's newspaper for lesbian, gay, bisexual, and transgender issues. Access: http://members.aol.com/oitm/ oitm.htm.

\section{Politics}

- Gay and Lesbian Politics: WWW and Internet Resources. This list is intended as a comprehensive resource on the roles, participation, attitudes, and behaviors of, and issues of concern to, gay men and lesbians in American politics. Access: http://ezinfo.ucs. indiana.edu/ sanderss/gaylespolguide.html.

- Queer Planet. An international list for gay, leshian, and bisexual persons who want to work as community organizers. Access: majordomo@vector.casti.com. Subscribe. "queerplanet."

\section{Domestic partnership}

- Domestic Partnerships and Same Sex Marriages. The best site for beginning research into this controversial issue. Areas covered include the precise legal definition of family, sample domestic partner policies (and a list of those companies and institutions that have them), and the same-sex marriage case currently being heard in Hawaii. Access: http:// www.cs.cmu.edu/afs/cs/cmu.edu/user/scotts/ domestic-partners/mainpage.html. 